Piotr Gajewski

Uniwersytet Gdański

\title{
DZIAŁALNOŚĆ GOSPODARCZA W ROZUMIENIU USTAWY O PODATKU OD TOWARÓW I USŁUG ORAZ USTAWY O PODATKU DOCHODOWYM OD OSÓB FIZYCZNYCH
}

\section{WSTĘP}

Celem ustawodawcy powinno być zapewnienie podatnikom pewności swojej sytuacji prawnej, co umożliwia autonomia prawa podatkowego. Autonomia prawa podatkowego to koncepcja umożliwiająca wprowadzanie do ustaw podatkowych definicji różniących się od rozumienia danej definicji w innej gałęzi prawa. Dzięki przyjęciu odmiennego rozumienia danej definicji w prawie podatkowym możliwe jest właściwe reagowanie na zmiany zachodzące w prawie podatkowym ${ }^{1}$.

Celem niniejszego artykułu będzie przedstawienie realizacji zasady autonomii prawa podatkowego w przepisach podatkowych, które mają na celu uregulowanie znaczenia pojęcia „działalność gospodarcza”. W opracowaniu zostaną przedstawione także skutki przyjęcia odmiennych definicji działalności gospodarczej niż ta określona w ustawie z 6 marca 2018 r. - Prawo przedsiębiorców (Dz. U. z 2019 r. poz. 1292 ze zm.), które ułatwiają stosowanie ustaw podatkowych, czyli ustawy

1 M. Koszowski, Autonomia prawa podatkowego - argumenty za i przeciw, «Przegląd Prawa Publicznego» 11/2013, s. 42-56. 
z 11 marca 2004 r. o podatku od towarów i usług (Dz. U. z 2018 r. poz. 2174 ze zm.) oraz ustawy z 26 lipca 1991 r. o podatku dochodowym od osób fizycznych (Dz. U. z 2019 r. poz. 1387 ze zm.). W niniejszym artykule w odniesieniu do badania aktów prawnych zostały wykorzystane następujące metody: metoda dogmatycznoprawna oraz metoda historycznoprawna. Badania zostały przeprowadzone przy użyciu krytycznej analizy orzecznictwa sądów administracyjnych oraz Trybunału Sprawiedliwości Unii Europejskiej.

W pierwszej kolejności należy wskazać, że art. 3 prawa przedsiębiorców stanowi, iż „działalnością gospodarczą jest zorganizowana działalność zarobkowa, wykonywana we własnym imieniu i w sposób ciągły”. Ustawa ta zawiera inną definicję działalności gospodarczej od tej z art. 2 poprzednio obowiązującej ustawy z 2 lipca 2004 r. o swobodzie prowadzenia działalności gospodarczej. Ustawodawca zrezygnował z wymienienia rodzajów działalności, które mają być uznawane za działalność gospodarczą - co zasługuje na pozytywną ocenę, ponieważ pozwala na uznawanie nowych rodzajów ludzkiej aktywności w obrocie gospodarczym za działalność gospodarczą. Paweł Borszowski uważa, że definicja działalności gospodarczej przedstawia zjawiska ekonomiczne w języku prawniczym². Pogląd ten zasługuje na aprobatę, gdyż tylko przez jak najbardziej prostą definicję, którą obecnie możemy znaleźć w ustawie Prawo przedsiębiorców, definicja legalna działalności gospodarczej będzie zawsze aktualna w stosunku do realiów obrotu gospodarczego.

\section{Dziąalność gospodarcza w ustawie Prawo}

PRZEDSIĘBIORCÓW A DEFINICJA W USTAWIE O PODATKU OD TOWARÓW I USŁUG

Definicja działalności gospodarczej w przepisach ustawy o podatku od towarów i usług (dalej: ustawa o VAT) jest określona w art. 15 ust. 2. Należy zgodzić się z poglądem, że prowadzenie działalności gospodarczej

2 P. Bonszowski, Działalność gospodarcza w konstrukcji prawnej podatku, Warszawa 2010, «Lex/el.» 
w rozumieniu ustawy o VAT zachodzi niezależnie od zdolności do czynności prawnych danego podmiotu ${ }^{3}$. Podatnik może podejmować czynności stanowiące działalność gospodarczą pomimo braku wpisu we właściwym rejestrze, który umożliwia uzyskanie statusu przedsiębiorcy ${ }^{4}$. Każdy przedsiębiorca prowadzi działalność gospodarczą w rozumieniu ustawy o VAT, lecz nie tylko zarejestrowane podmioty we właściwym rejestrze albo ewidencji mogą prowadzić działalność gospodarczą w rozumieniu ustawy o VAT.

Ustawodawca w obrębie jednej jednostki redakcyjnej sformułował dwie definicje dotyczące działalności gospodarczej w ustawie o VAT. Pierwsze zdanie art. 15 ust. 2 ustawy o VAT stanowi wymienienie rodzajów ról, jakie przyjmować mogą podatnicy w obrocie gospodarczym. Jest to uzasadnione zasadą neutralności podatku VAT.

Zasada neutralności podatku VAT to dyrektywa, zgodnie z którą to ostateczny konsument danego towaru lub usługi powinien ponosić ciężar ekonomiczny podatku VAT ${ }^{5}$. W związku z tym konieczne było wymienienie przez ustawodawcę wszystkich rodzajów ról występujących w obrocie gospodarczym, aby podatek od towarów i usług został pobrany na każdym etapie nabywania towaru lub usługi, aż do ostatecznego nabycia danego towaru lub usługi w celu jego konsumpcji - wyrażona przez to jest zasada objęcia opodatkowaniem konsumpcji.

Drugie zdanie art. 15 ust. 2 ustawy o VAT stanowi katalog czynności, do jakich dochodzi w obrocie gospodarczym. Nie jest możliwe prowadzenie działalności gospodarczej w taki sposób, aby nie dochodziło do wykorzystywania towarów lub wartości niematerialnych i prawnych. Każda działalność ludzka zasadniczo opiera się na wykorzystywaniu towarów lub wartości niematerialnych i prawnych w celu wytworzenia czegoś nowego na bazie wykorzystywanych towarów lub wartości.

Istotą uznania działalności za działalność gospodarczą w rozumieniu art. 15 ust. 2 zd. 2 ustawy o VAT jest podejmowanie aktywnych działań

\footnotetext{
A. RutKowska-Brdulak, Stałe miejsce prowadzenia działalności w VAT a podmiotowość prawnopodatkowa. Dylematy, konsekwencje, ryzyka, Warszawa 2018, s. 43. Ibidem, s. 45.

D. Gibasiewicz, Zasada neutralności podatku od wartości dodanej w orzecznictwie Trybunału Sprawiedliwości Unii Europejskiej, Warszawa 2012, LEX/el.
} 
w zakresie obrotu (w tym stanie faktycznym nieruchomościami), które miały na celu przygotowanie danej nieruchomości do celów handlowych oraz rozreklamowanie sprzedaży danych nieruchomości ${ }^{6}$. Należy przychylić się do tego poglądu, ponieważ to ciągłość i zarobkowość działalności powinny przesądzać o charakterze działalności gospodarczej danej działalności, a nie osiągane przychody przez przedsiębiorcę albo liczba transakcji zawartych przez niego w danym czasie.

Samo podejmowanie handlowych czynności prawnych nie powinno przesądzać o charakterze działalności, jeżeli brakuje elementów związanych z ciągłością i zorganizowaniem danej działalności. Jednakże liczba przeprowadzonych transakcji przez podmiot może, wraz z innymi okolicznościami (takimi jak zorganizowanie i ciągłość transakcji), świadczyć o tym, że dana działalność posiada przymioty działalności gospodarczej ${ }^{7}$. Pogląd ten jest słuszny - ustalenie dużej liczby transakcji przeprowadzanej przez dany podmiot może wskazywać, że jego działalność jest zorganizowana i ciągła oraz ma zarobkowy charakter - co będzie świadczyło, iż działalność stanowi działalność gospodarczą.

Trudno zgodzić się natomiast ze stwierdzeniem WSA w Olsztynie, według którego ustawodawca zapomniał przewidzieć w art. 15 ust. 1 oraz art. 15 ust. 2 ustawy o VAT okoliczność, że majątek prywatny osoby fizycznej może być sprzedawany jako przedmiot działalności gospodarczej albo jako zwykłe wykonywanie prawa własności ${ }^{8}$.

Po pierwsze, nie sposób uznać, aby osoba fizyczna dokonująca przykładowo sprzedaży swojego mieszkania była handlowcem w rozumieniu art. 15 ust. 2 zd. 1 ustawy o VAT, ponieważ handlowcem w rozumieniu tegoż przepisu powinien być podmiot, który wykonuje profesjonalną działalność polegającą na dokonywaniu sprzedaży towarów, a nie osoba, która dokonała jednokrotnie czynności prawnej będącej umową

\footnotetext{
Wyrok WSA w Łodzi z 22 listopada 2016 r., I SA/Łd 904/16, «Lex» nr 2175653. Wyrok NSA z 28 listopada 2014 r., I FSK 1899/13, «Lex» nr 1590759.

8 Wyrok WSA w Olsztynie z 11 marca 2015 r., I SA/Ol 51/15, «Lex» nr 1660873.
} 
sprzedaży - pogląd ten potwierdzony jest zarówno w doktrynie ${ }^{9}$, jak i w orzecznictwie sądowoadministracyjnym ${ }^{10}$.

Po drugie, dokonanie jednorazowej sprzedaży nieruchomości należącej do prywatnego majątku nie będzie posiadało waloru ciągłości działalności gospodarczej.

Po trzecie, wątpliwości budzi uznanie czynności podjętej w celu sprzedaży majątku prywatnego za zorganizowaną, ponieważ podmiot nietrudniący się profesjonalnie obrotem nieruchomościami może nie być w pełni świadomy, jak w sposób najbardziej efektywny dokonywać czynności związanych z przygotowaniem nieruchomości do sprzedaży oraz czynności związanych z zawarciem umowy sprzedaży.

Podobnie uważa Trybunał Sprawiedliwości Unii Europejskiej - prowadzenie działalności gospodarczej polega na korzystaniu ze środków w sposób profesjonalny. Ponadto, jeżeli osoba fizyczna niebędąca przedsiębiorcą dokonuje czynności w ramach zarządu własnym majątkiem, to nie można uznać takowej czynności za prowadzenie działalności gospodarczej ${ }^{11 .}$ Ta ki sam pogląd wyraził NSA ${ }^{12}$, a w doktrynie stanowisko to potwierdziła Agnieszka Wesołowska ${ }^{13}$. Trybunał Sprawiedliwości Unii Europejskiej nakazuje również zbadanie wszystkich okoliczności

9 K. KŁosкowsкi, Sprzedaż nieruchomości przez osoby fizyczne nieprowadzace działalności gospodarczej a status podatnika na gruncie VAT, «Doradztwo Podatkowe» 2/2007, s. 11.

10 Wyrok NSA z 16 maja 2012 r., I FSK 1050/11, «Lex» nr 1292446.

11 Wyrok TSUE z 15 września 2011 r., C-180/10 i C-181/10, ZOTSiS 2011/8-9B/I-8461-8493.

12 Wyrok NSA z 3 marca 2015 r., I FSK 1859/13, «Lex» nr 1651672, oraz wyrok NSA z 26 maja 2017 r., I FSK 1728/15, «Lex» nr 2307399. W wyroku I FSK 1728/15 NSA wypowiada się co prawda, wyjaśniając pojęcie działalności gospodarczej zawarte w art. 9 ust. 1 dyrektywy 2006/112/WE Rady z 28 listopada 2006 r. w sprawie wspólnego systemu podatku od wartości dodanej (dalej: dyrektywa o VAT), lecz definicja w ustawie o VAT stanowi implementację dyrektywy o VAT, co zdaniem autora uzasadnia odniesienie się do wyroku dotyczącego dyrektywy o VAT.

13 A. WesoŁowska, Pojęcie „podatnika” oraz „osoby prowadzącej działalność gospodarcza" dla potrzeb podatku VAT. Glosa do wyroku TS z 13 czerwca 2013 r., C-62/12, Warszawa 2013, LEX/el. 
użytkowania majątku, aby ustalić, czy jest on wykorzystywany do celów prywatnych czy do prowadzenia działalności gospodarczej ${ }^{14}$.

Należy zwrócić uwagę, że art. 15 ust. 2 zd. 2 ustawy o VAT nie zawiera konieczności istnienia cechy zorganizowania działalności gospodarczej, aby działalność prowadzona przez podatnika była uznawana za działalność gospodarczą w rozumieniu ustawy o VAT. Jednakże sądy administracyjne ${ }^{15}$ uznają „zorganizowanie” jako cechę działalności gospodarczej w rozumieniu art. 15 ust. 2 ustawy o VAT. Należy zgodzić się z poglądem sądów administracyjnych, ponieważ zarówno ustawa - Prawo przedsiębiorców, jak i ustawa o podatku dochodowym od osób fizycznych uznają „zorganizowanie” jako element działalności gospodarczej.

Ponadto, nie jest możliwe realizowanie ciągłości działalności gospodarczej bez jej zorganizowania. Bez utworzenia struktury organizacyjnej utrudnione byłoby podejmowanie czynności w sposób ciągły, ponieważ każda czynność wymagałaby odrębnego zaplanowania. Dzięki zorganizowaniu działalności można stworzyć pewne schematy działania, ułatwiające szybsze i bardziej efektywne wykonywanie czynności związanych z działalnością gospodarczą.

Naczelny Sąd Administracyjny stwierdza, że ciągłość działalności gospodarczej cechuje się dużą liczbą transakcji wykonanych w ciągu każdego poszczególnego miesiąca danego roku podatkowego ${ }^{16}$. W związku z tym utrudnione byłoby zachowanie ciągłości działalności gospodarczej bez jej zorganizowania. Podmiot niecechujący się zorganizowaniem nie byłby w stanie wykonywać sprawnie wielu transakcji każdego miesiąca. Niezorganizowany podmiot byłby nieefektywny ekonomicznie, co stawiałoby go na gorszej pozycji w obrocie gospodarczym.

Obie definicje działalności gospodarczej są ze sobą w stosunku zamienności - obydwie definicje są ze sobą związane. Nie istnieje taki rodzaj działalności, który nie pokrywałby się z jakąś z obydwu definicji. Rodzaje aktywności podejmowanej w obrocie gospodarczym

14 Wyrok TSUE z 19 lipca 2012 r., C-263/11, ZOTSiS 2012/7/I-497.

15 Wyrok WSA w Szczecinie z 3 lipca 2013 r., I SA/Sz 904/12, «Lex» nr 1348401, oraz wyrok NSA z 11 czerwca 2015 r., I FSK 716/14, «Lex» nr 1772904.

16 Wyrok NSA z 13 maja 2015 r., I FSK 154/14, «Lex» nr 1772615. 
wymienione w zdaniu drugim art. 15 ust. 2 ustawy o VAT skutkują przyjęciem w obrocie gospodarczym jednej z ról wymienionych w zdaniu pierwszym tego artykułu.

Przytoczyć trzeba także art. 15 ust. 6 ustawy o VAT, na mocy którego nie uznaje się za podatnika organów władzy publicznej oraz ich urzędów, jeżeli wykonują zadania nałożone na nie poprzez przepisy prawa, z wyjątkiem zadań wykonywanych na podstawie umów cywilnoprawnych. Ustawodawca słusznie rozgraniczył sytuacje, kiedy organy władzy publicznej działają w sferze publicznej albo prywatnej. Nie sposób znaleźć ekonomicznego uzasadnienia dla obciążania obowiązkami instrumentalnymi działań, które są wykonywane w imieniu organów władzy publicznej.

Z drugiej strony, w sytuacji kiedy organy władzy publicznej działają jako podmiot prawa cywilnego, to uzasadnione jest nałożenie obowiązku podatkowego na działania związane z obrotem gospodarczym, gdyż ma to na celu zapewnienie równości działalności gospodarczej.

Obie definicje działalności gospodarczej zawarte w art. 15 ust. 2 ustawy o VAT należy rozpatrywać łącznie dla rzeczywistego ustalenia, czym jest działalność gospodarcza w rozumieniu ustawy o VAT. Przykładem potwierdzającym konieczność dokonywania wykładni pojęcia działalności gospodarczej w rozumieniu ustawy o VAT jest orzeczenie, w którym NSA orzekł, że żona pomagająca mężowi w prowadzeniu działalności gospodarczej nie jest osobą prowadzącą działalność gospodarczą ${ }^{17}$.

Zgodnie $\mathrm{z}$ treścią art. 15 ust. 2 zd. 1 ustawy o VAT można by było uznać, że żona prowadziła wraz z mężem działalność gospodarczą, ponieważ działalność gospodarcza to „wszelka działalność usługodawców”, czyli także nadawanie przesyłek i odbieranie przekazów pocztowych w celu prowadzenia działalności gospodarczej. Jednakże nie dokonywała tego z powodu chęci osiągnięcia własnych celów zarobkowych, a jej działaniu można było przypisać cechę niezarobkowego postępowania „Z grzeczności”. Mąż prosił żonę o wykonywanie pewnych czynności na jego prośbę, a nie prowadził wspólnie z nią działalności gospodarczej.

17 Wyrok NSA z 16 maja 2018 r., I FSK 1330/16, «Lex» nr 2511320. 
Ponadto, mąż dokonywał planowania zawartości i przeznaczenia danej przesyłki. W związku z tym nie można uznać, że w tym stanie faktycznym żona była wspólnikiem swojego męża w prowadzonej działalności gospodarczej.

Wojewódzki Sąd Administracyjny w Szczecinie wskazuje, że dla uznania działalności za działalność gospodarczą muszą występować między innymi „aktywne działania, pozwalające na uczestnictwo w obrocie gospodarczym"18. W powyższym stanie faktycznym to mąż podejmował działania takiego rodzaju, a żona tylko dorywczo pomagała małżonkowi. Takie zachowanie uniemożliwia uznanie jej za osobę współprowadzącą działalność gospodarczą.

Wojewódzki Sąd Administracyjny w Poznaniu orzekł, że dla przyjęcia wykonywania roli handlowca przez dany podmiot należy ustalić, czy wykonywał on czynności w sposób profesjonalny oraz zorganizowany, dążący do osiągnięcia pewnego celu ekonomicznego ${ }^{19}$. W doktrynie pogląd ten potwierdzają Trajan Szuladziński ${ }^{20}$ oraz Jacek Budziszewski i Anna Żarkowska ${ }^{21}$.

Pogląd wyrażony przez WSA w Poznaniu jest bardzo istotny przy ocenianiu danej działalności za działalność gospodarczą. Nie można przecież uznać działalności za profesjonalną, jeżeli składa się tylko z jakichś pojedynczych, niepowiązanych ze sobą części, bez dążenia do osiągnięcia celu ekonomicznego. Każda działalność w obrocie gospodarczym powinna być uzasadniona osiągnięciem pewnego celu ekonomicznego. Jeżeli ktoś bez celu osiągnięcia korzyści majątkowej, „Z grzeczności” pomoże jednorazowo w osiągnięciu innemu podmiotowi

18 Wyrok WSA w Szczecinie z 11 kwietnia 2018 r., I SA/Sz 120/18, «Lex» nr 2475285.

19 Wyrok WSA w Poznaniu z 27 września 2017 r., I SA/Po 773/17, «Lex» nr 2366385.

20 T. Szuladziński, Podatnik VAT $w$ nieprofesjonalnym obrocie gospodarczym istotna zmiana interpretacji, «Nowy Przegląd Notarialny» 3/2011, s. 85-89, oraz T. SzULADZIŃsKI, Definicja podatnika a opodatkowanie sprzedaży nieruchomości podatkiem od czynności cywilnoprawnych i VAT, «Nowy Przegląd Notarialny» 4/2005, s. 87.

${ }^{21}$ J. Budziszewski, A. ŻARKowsKa, Opodatkowanie dostawy udziału w prawie wieczystego użtkowania niezabudowanej działki gruntu, «Doradztwo Podatkowe» 12/2014, s. 9-11. 
celu ekonomicznego, to nie można takiego zachowania uznać za wykonywanie działalności gospodarczej.

Trudno się zgodzić z odmiennym poglądem wysuwanym przez WSA w Olsztynie, zdaniem którego można zaliczyć ubocznie wykonywane czynności przez osobę będącą przedsiębiorcą, niezwiązane bezpośrednio z prowadzonym przedsiębiorstwem za czynności związane z działalnością gospodarczą ${ }^{22}$. Fakt bycia przedsiębiorcą nie może bowiem powodować sytuacji, w której każdą czynność wykonaną przez osobę prowadzącą działalność gospodarczą uznaje się za wykonywanie działalności gospodarczej, nawet jeżeli dana czynność nie zamierza osiągnąć celu ekonomicznego w ramach prowadzonego przedsiębiorstwa.

3. Dziąalność nieewidencjowana w ustawie - Prawo PRZEDSIĘBIORCÓW A DEFINICJA DZIAŁALNOŚCI GOSPODARCZEJ Z USTAWY O VAT

Wątpliwości może budzić przeciwstawienie definicji zawartych w art. 15 ust. 2 ustawy o VAT pojęciu działalności nieewidencjowanej, regulowanej przez art. 5 prawa przedsiębiorców. Przepisy ustawy o VAT nie wyłączają działalności nieewidencjonowanej od uznania jej za działalność gospodarczą. Jednakże na mocy art. 113 ust. 1 ustawy o VAT działalność o poziomie dochodów określonym w art. 5 ust. 1 prawa przedsiębiorców będzie podlegała zwolnieniu jako sprzedaż nieprzekraczająca łącznie w poprzednim roku podatkowym kwoty 200000 zł.

Warte rozważenia byłoby jednak zastosowanie wyłączenia podatkowego dla podatnika osiągającego przychody poniżej wysokości przychodu należnego z działalności określonego w art. 5 ust. 1 prawa przedsiębiorców. Wprowadzenie instytucji „działalności nieewidencjonowanej” do polskiego porządku prawnego miało na celu wspieranie w prowadzeniu działalności zarobkowej przez osoby fizyczne, dla których byłoby to dodatkowe zajęcie, niestanowiące głównego źródła przychodu. Utworzenie takowego wyłączenia ułatwiłoby prowadzenie

22 Wyrok WSA w Olsztynie z 27 lipca 2017 r., I SA/Ol 313/17, «Lex» nr 2338296. 
działalności nieewidencjonowanej, ponieważ podmiot ją prowadzący mógłby uniknąć konieczności udowadniania, że osiągnął przychody ze sprzedaży w wysokości poniżej progu przewidzianego w art. 113 ust. 1 ustawy o VAT. Taka regulacja doprowadziłaby do pełniejszego zrealizowania idei przyświecającej ustawodawcy przy tworzeniu art. 5 prawa przedsiębiorców.

W związku z pojęciem działalności nieewidencjonowanej należy wspomnieć o pojęciu małego podatnika w rozumieniu ustawy o VAT oraz rozważyć stosunek pomiędzy pojęciem małego podatnika w przypadku ziszczenia się warunku zawartego w art. 2 pkt 25 lit. a ustawy o VAT a pojęciem mikroprzedsiębiorcy w ustawie Prawo przedsiębiorców. Porównanie tych pojęć jest istotne, ponieważ reżim prawny przewidziany dla małego podatnika w ustawie o VAT powinien być tożsamy z pojęciem mikroprzedsiębiorcy w rozumieniu ustawy - Prawo przedsiębiorców. Umożliwiałoby to ograniczenie obowiązków nakładanych na podatnika, który jest mikroprzedsiębiorcą, lecz nie spełnia wymogów, aby był poczytywany za małego podatnika.

Objęcie każdego mikroprzedsiębiorcy statusem małego podatnika oraz wyłączenie od podatku VAT działalności nieewidencjonowanej stanowiłoby przejaw funkcji stymulacyjnej podatków. Funkcja stymulacyjna podatków polega na regulowaniu zasobów podatnika poprzez zapewnienie ochrony minimalnego poziomu dochodu oraz zwiększenie wzrostu gospodarczego ${ }^{23}$. Osobom prowadzącym działalność gospodarczą zapewniono by dodatkowe udogodnienia, które umożliwiłyby rozwój mikroprzedsiębiorstw oraz ułatwiły prowadzenie działalności nieewidencjonowanej.

Co prawda każdy podmiot prowadzący działalność nieewidencjonowaną korzysta, na podstawie art. 113 ust. 1 ustawy o VAT, z podmiotowego zwolnienia podatkowego, obejmującego podatników, u których wartość sprzedaży nie przekroczyła łącznie w poprzednim roku podatkowym kwoty 200000 zł. Wyłączenie podatkowe jednak umożliwiłoby podmiotom prowadzącym działalność nieewidencjowaną uniknięcie jakichkolwiek obowiązków związanych z podatkiem od towarów i usług.

23 K. NizioŁ, Prawne aspekty polityki podatkowej, Warszawa 2007, s. 105-106. 
Korespondowałoby to z uzasadnieniem ustawy - Prawo przedsiębiorców, w której ustawodawca określił, że działalność nieewidencjowana ma na celu między innymi zapewnienie braku formalnych obowiązków typowych dla działalności gospodarczej.

Byłoby to również zgodne z celem motywu 49 dyrektywy 2006/112/ WE Rady z 28 listopada 2006 r. w sprawie wspólnego systemu podatku od wartości dodanej, który zezwala na utrzymywanie procedur szczególnych dotyczących małych przedsiębiorców. Terminu małych przedsiębiorców nie należy tutaj rozumieć dosłownie jako małych przedsiębiorców w rozumieniu ustawy - Prawo przedsiębiorców, ale jako te kategorie przedsiębiorców, którym na gruncie polskiego systemu prawnego przysługuje specjalna ochrona ich praw. Na podstawie preambuły ustawy z 6 marca 2018 r. o Rzeczniku Małych i Średnich Przedsiębiorców są to mikroprzedsiębiorcy, mali przedsiębiorcy oraz średni przedsiębiorcy. Artykuł 395 ust. 1 przywoływanej dyrektywy umożliwia państwom członkowskim Unii Europejskiej odstępstwa od przepisów dyrektywy w celu uproszczenia poboru podatku VAT, jeżeli nie spowoduje to znaczącego obniżenia ogólnej kwoty wpływów z podatków państwa członkowskiego pobieranych na etapie ostatecznej konsumpcji.

W preambule ustawy - Prawo przedsiębiorców ustawodawca ogłasza, że jego celem jest ochrona i wspieranie wolności działalności gospodarczej $^{24}$. Co prawda wprowadzenie postulowanych powyżej zmian spowoduje, że zachwiana będzie równość działalności gospodarczej, niemniej nie jest możliwe zapewnienie równocześnie wolności i równości działalności gospodarczej ${ }^{25}$. W tej sytuacji trzeba przyjąć, że dla wzrostu gospodarczego oraz podatników korzystniejsze będzie zapewnienie wolności działalności gospodarczej poprzez uproszczenie jej działania za pomocą postulowanych zmian. Ułatwienie prowadzenia działalności gospodarczej pobudzi podmioty do osiągania większych zysków ekonomicznych, co niewątpliwie przełoży się na rozwój przedsiębiorstw.

24 Zob. szerzej P. Gajewski, Polityka ustawodawcy $w$ zakresie podejmowania, wykonywania i zakończenia działalności gospodarczej, «Studenckie Zeszyty Naukowe» 21.38/2018, s. 45-46.

25 Ibidem, s. 50. 
4. Dziąalność gospodarcza w ustawie Prawo PRZEDSIĘBIORCÓW A W USTAWIE O PODATKU DOCHODOWYM OD OSÓB FIZYCZNYCH

Ustawodawca nie dokonał zmian w definicji działalności gospodarczej, która jest zawarta w art. 5a pkt 6 ustawy o podatku dochodowym od osób fizycznych (dalej: ustawa o PIT) w związku z uchwaleniem ustawy - Prawo przedsiębiorców. Definicja z ustawy o PIT była oparta na definicji zawartej w art. 2 ustawy z 2 lipca 2004 r. o swobodzie działalności gospodarczej. Ustawodawca nie mógł się jednak wprost odnieść do przepisów ustawy regulującej zasady prowadzenia działalności gospodarczej, ponieważ uznaje się, że definicja jest tworzona na podstawie danego aktu normatywnego ${ }^{26}$.

Pogląd ten wydaje się słuszny pomimo tego, że ustawodawca chciałby przenieść takie samo brzmienie przepisu prawnego, jednak jego wykładnia na gruncie innej ustawy niż ta, gdzie się dany przepis pierwotnie znajduje, może być inna. Organy administracji oraz sądy mogą interpretować przepis w odmienny sposób na potrzeby różnych gałęzi prawa. Jednakże dla celów ustawy o PIT trzeba posługiwać się wyłącznie definicją zawartą w ustawie o PIT $^{27}$.

Należy negatywnie ocenić brak dokonania zmian w art. 5a pkt 6 ustawy o PIT. Ustawodawca nie powinien doprowadzać do sytuacji, w której dokonuje wyliczenia rodzajów działalności uważanych za działalność gospodarczą. Obrót gospodarczy podlega ciągłym zmianom, w związku z tym nie można zamykać drogi do uznawania nowych, nieznanych obecnie rodzajów ludzkiej aktywności w obrocie gospodarczym za działalność gospodarczą.

Ponadto, zdaniem WSA w Gdańsku, dla prowadzenia działalności gospodarczej w rozumieniu ustawy o PIT nie jest wymagana organizacja działalności gospodarczej w znaczeniu instytucjonalnym ${ }^{28}$. Pogląd ten znalazł poparcie również w orzeczeniu $\mathrm{NSA}^{29}$. Zorganizowania

B. Brzeziński, Podstawy wykładni prawa podatkowego, Gdańsk 2018, s. 74.

Wyrok WSA w Opolu z 28 marca 2008 r., I SA/Op 382/07, «Lex» nr 477433.

Wyrok WSA w Gdańsku z 6 czerwca 2017 r., I SA/Gd 499/17, «Lex» nr 2323258.

Wyrok NSA z 7 marca 2017 r., II FSK 2355/15, «Lex» nr 2279343. 
w rozumieniu art. 5 a pkt 6 ustawy o PIT nie można pojmować jako zorganizowania instytucjonalnego, tylko jako podejmowanie określonych, powtarzających się czynności dla wykonywania działalności. Może się zdarzyć tak, że dany podmiot wykonuje działalność bez zarejestrowania jej w KRS albo CEIDG.

Brak organizacji instytucjonalnej danego przedsiębiorcy nie może oznaczać, ze będzie on wolny od powinności związanych z opodatkowaniem. Wynika stąd uzasadnienie dla definiowania działalności gospodarczej w ustawach podatkowych. Ustawodawca powinien jednak pamiętać, że definicja w ustawie podatkowej nie może pomijać pojmowania działalności gospodarczej na gruncie ustawy - Prawo przedsiębiorców.

Definicja zawarta w ustawie dotyczącej prowadzenia działalności gospodarczej może być tylko rozszerzana o nowe rodzaje działalności, nieznane w definicji zawartej w ustawie Prawo przedsiębiorców, albo o takie rodzaje działalności, jakie nie są uznawane za działalność gospodarczą w rozumieniu ustawy regulującej prowadzenie działalności gospodarczej. Definicje działalności gospodarczej zawarte w ustawach podatkowych powinny być zawsze dostosowywane do realiów obrotu gospodarczego, w którym mogą powstawać nowe typy umów nieznane do tej pory prawodawstwu.

Ponadto, brak formalnego zarejestrowania działalności gospodarczej przez podatnika nie może skutkować nieuznaniem takiego podatnika za prowadzącego działalność gospodarczą w rozumieniu ustawy o PIT $^{30}$. Należy uznać takowy pogląd za słuszny, ponieważ odmienny pogląd mógłby doprowadzać do omijania prawa poprzez brak rejestrowania działalności gospodarczej w celu niepowstawania obowiązku podatkowego. Podobny pogląd wyraża również Aneta Nowak-Piechota ${ }^{31}$. Przepis art. 5a pkt 6 ustawy o PIT wspomina co prawda o zorganizowaniu przedsiębiorstwa, lecz niezgodna z przepisami prawa organizacja przedsiębiorstwa nie powoduje, że działalności gospodarczej nie można

\footnotetext{
30 Wyrok WSA w Warszawie z 19 czerwca 2015 r., I SA/Wa 2729/14, «Lex» nr 1972068.

31 A. Nowak-Piechota, [w:] Opodatkowanie działalności gospodarczej w Polsce, red. A. MARIAŃski, Warszawa 2016, LEX/el.
} 
uznać za zorganizowaną. Dla uznania działalności gospodarczej za zorganizowaną wystarczy, aby powstały jakiekolwiek zręby struktury organizacyjnej - nie muszą być one efektywne ani zgodne z przepisami prawa.

Zdaniem WSA w Olsztynie przesłanek wykonywania działalności gospodarczej w rozumieniu ustawy o PIT nie można rozpatrywać tylko w odniesieniu do danego roku podatkowego, ale rozpatrując prowadzenie działalności w całym czasie jej wykonywania ${ }^{32}$. Wydaje się, że pogląd jest niesłuszny. Każdego roku powstaje nowe zobowiązanie podatkowe, dlatego wydaje się słuszne coroczne rozpatrywanie, czy podatnik wykonywał działalność gospodarczą w danym roku podatkowym. W sytuacji, gdyby działalność wykonywana przez podatnika we wcześniejszych latach stanowiła działalność gospodarczą, a w danym roku podatkowym nie stanowiła już działalności takiego rodzaju, to nie można na podatnika nakładać obowiązku podatkowego tylko z tego powodu, że we wcześniejszych latach działalność, którą się parał, stanowiła działalność gospodarczą, z których zostało już zaspokojone zobowiązanie podatkowe.

Wątpliwości może budzić fakt, że ustawodawca w art. 5a pkt 6 ustawy o PIT ustanowił jednakowe znaczenie definicji działalności gospodarczej i pozarolniczej działalności gospodarczej. Zgodnie z zasadą lege non distinguente ustawodawca nie powinien nadawać różnym określeniom tego samego znaczenia. Poza tym ustawa - Prawo przedsiębiorców stanowi w art. 6 ust. 1, że działalność rolnicza jest działalnością gospodarczą, lecz nie stosuje się do niej ustawy - Prawo przedsiębiorców. W związku z powyższym ustawodawca powinien zrezygnować $\mathrm{z}$ nadawania takiego samego znaczenia różnym definicjom. Z zastosowania wyrazu „pozarolnicza” można uznać, że zasadniczo każdą działalnością rolniczą będzie działalność wymieniona w art. 2 ust. 2 ustawy o PIT. Wydaje się słuszne przyjęcie poglądu, że art. 2 ust. 2 ustawy o PIT reguluje możliwe rodzaje aktywności osoby trudniącej się rolnictwem, które są wyłączone od stosowania do nich ustawy o PIT.

32 Wyrok WSA w Olsztynie z 21 listopada 2018 r., I SA/Ol 613/18, «Lex» nr 2593853. 
Może dojść do sytuacji, w której podczas danej czynności prawnej podmiot będący podmiotem wykonującym działalność gospodarczą w rozumieniu ustawy o PIT nie będzie działał w danej sytuacji jako podmiot wykonujący działalność gospodarczą. W stosunku do stanu faktycznego, w którym przedsiębiorca zawarł umowę najmu, która zawierała także rzeczy związane z wykonywaną przez niego działalnością gospodarczą, wypowiedział się WSA w Gdańsku. Jego zdaniem w takiej sytuacji przychody z tytułu najmu będą stanowiły przychody z tytułu działalności gospodarczej ${ }^{33}$.

Pogląd ten trudno uznać za pogląd słuszny. O charakterze umowy najmu jako działalności gospodarczej powinien decydować zamiar działania jako podmiot wykonujący działalność gospodarczą poprzez zawarcie umowy najmu, a nie charakter pewnych składników umowy najmu jako składników związanych z wykonywaniem działalności gospodarczej. Takie zachowanie nie wypełnia definicji działalności gospodarczej. W tym stanie faktycznym nastąpiło działanie jednorazowe, które nie nastąpiło w związku z wykonywaniem działalności gospodarczej.

Naczelny Sąd Administracyjny uznaje zaś, że pojedyncze zachowanie nie stanowi działalności gospodarczej w rozumieniu ustawy o PIT $^{34}$. Należy mieć jednak na uwadze fakt, że przedsiębiorca powinien dopuścić się czynności mających na celu zmianę charakteru wynajętych składników na rzeczy niezwiązane z działalnością gospodarczą przed ich wynajęciem. Pogląd ten nie stanowi negacji kryterium obiektywnego prowadzenia działalności gospodarczej jako przesądzającego o jej prowadzeniu.

Mimo kryterium obiektywności trzeba uznać, że w sytuacji gdy o uznaniu danej czynności za wykonywanie działalności gospodarczej miałby tylko decydować fakt, iż kilka z przedmiotów danej umowy najmu jest związanych z wykonywaniem tej działalności, to uznanie takiej umowy za wykonywanie działalności gospodarczej byłoby niezgodne $\mathrm{z}$ istotą jej prowadzenia. Jeżeli dany podmiot będący przedsiębiorcą

\footnotetext{
33 Wyrok WSA w Gdańsku z 13 listopada 2018 r., I SA/Gd 914/18, «Lex» nr 2589172.

34 Wyrok NSA z 30 listopada 2016 r., II FSK 3223/14, «Lex» nr 2190551, oraz wyrok NSA z 25 lipca 2012 r., II FSK 2393/11, «Lex» nr 1219219.
} 
nie działał przy danej czynności w sposób profesjonalny, to nie można uznać, że tylko z tego powodu taka czynność będzie wykonywaniem działalności gospodarczej.

Naczelny Sąd Administracyjny wykreował pewnego rodzaju wzorzec zachowania cechującego podmiot działający jako podmiot wykonujący działalność gospodarczą i jest to „zespół powiązanych ze sobą działań podatnika, powtarzalnych, uporządkowanych, konsekwentnie prowadzących do osiągnięcia zysku, w szczególności łącznie polegających na wielokrotnym nabywaniu nieruchomości, ich zaawansowanym przygotowaniu do sprzedaży (tzn. w sposób wykraczający poza zwykły zarząd mieniem), wielorazowym zbywaniu w celu zarobkowym odpowiednio przygotowanych nieruchomości oraz dokonywaniu tych transakcji (nabycia i zbycia) w stosunkowo krótkim przedziale czasowym" ${ }^{35}$. Podobnie wypowiedział się Marcin Jamroży - jego zdaniem za działalność gospodarczą można uznać tylko takie czynności, które są funkcjonalnie powiązane z prowadzoną działalnością gospodarczą ${ }^{36}$.

Obok powyżej wspomnianego stanu faktycznego należy się zastanowić, czy prokurent osiąga przychody z działalności gospodarczej. Naczelny Sąd Administracyjny uznał, że wykonywanie prokury nie skutkuje osiąganiem przychodów z tytułu działalności gospodarczej ${ }^{37}$. Jest to pogląd słuszny, ponieważ prokurent działa w imieniu swojego mocodawcy i czynności wykonywane przez niego skutkują osiąganiem przychodów u mocodawcy, a nie u prokurenta. Wynagrodzenia prokurenta nie można poczytywać jako przychodów z działalności gospodarczej, tylko ze stosunku wewnętrznego łączącego prokurenta z mocodawcą, chyba że prokurent prowadziłby działalność gospodarczą polegającą na reprezentowaniu swoich klientów. W świetle powyższego nie można zgadzać się z odmiennym poglądem WSA w Krakowie ${ }^{38}$.

Naczelny Sąd Administracyjny sformułował warunki, które powinna spełnić dana czynność, aby można było ją uznać za prowadzenie

35 Wyrok NSA z 9 maja 2018 r., II FSK 1202/16, «Lex» nr 2511382.

36 M. Jamroży, Działalność gospodarcza czy inne źródło przychodów - łamigłówka nie do rozwiązania?, «Przegląd Podatkowy»10/2014, s. 7-9.

37 Wyrok NSA z 21 sierpnia 2015 r., II FSK 1491/13, ONSAiWSA 2016/6/98.

38 Wyrok WSA w Krakowie z 15 stycznia 2013 r., I SA/Kr 1405/12, «Lex» nr 1273952. 
działalności gospodarczej. Są to: „z góry założony cel ekonomiczny, istnienie elementu ciągłości danych czynności, stwierdzenie istnienia celu zarobkowego oraz ustalenie, czy do zbycia dochodzi w warunkach zorganizowania" ${ }^{39}$. Należy zgodzić się z warunkami wskazanymi przez NSA, a zwłaszcza z warunkiem zorganizowania czynności. Warunek zorganizowania danej czynności jest najważniejszy spośród warunków przesądzających o uznaniu danej czynności za wykonywanie działalności gospodarczej. Za wykonywanie działalności gospodarczej nie można uznać bowiem czynności, które nie są wykonywane przez podmiot, który posiada struktury organizacyjne oraz stały schemat działania przy wykonywaniu danej czynności, z którymi jest obeznany.

\section{WNIOSKI}

Z niniejszego wywodu wynika, że ustawodawca zrealizował zasadę autonomii prawa podatkowego odnośnie do zdefiniowania działalności gospodarczej w ustawie o PIT oraz ustawie o VAT. Właściwe zdefiniowanie działalności gospodarczej w tych ustawach jest o tyle istotne, że ustalenie wykonywania przez podatnika działalności gospodarczej wpływa na prawnopodatkową sytuację podatnika oraz jego kontrahentów. Wydaje się słuszne przyjęcie, że realizacja autonomii prawa podatkowego, którą można zauważyć w ustawie o podatku od towarów i usług oraz podatku dochodowym od osób fizycznych, nastąpiła zgodnie $\mathrm{z}$ jednym $\mathrm{z}$ ujęć autonomii prawa podatkowego wskazanych przez Macieja Koszowskiego. Chodzi o ujęcie, w którym co do zasady o ile poszczególne pojęcia zawarte $\mathrm{w}$ aktach prawa podatkowego są tożsame $\mathrm{z}$ innymi gałęziami prawa, o tyle pojęcia $\mathrm{w}$ prawie podatkowym mogą być zdefiniowane w sposób odmienny ${ }^{40}$. Pomimo tego, że w ustawie o VAT albo o PIT znajdują się odmienne definicje działalności gospodarczej, to celem ustawodawcy było niewątpliwie jak najszersze wykorzystywanie dorobku publicznego prawa gospodarczego do rozpatrywania

39 Wyrok NSA z 3 lipca 2018 r., II FSK 2299/16, «Lex» nr 2529130.

40 M. Koszowski, op. cit., s. 42-56. 
wątpliwości dotyczących definicji działalności gospodarczej na gruncie przepisów prawa podatkowego - pogląd ten znajduje potwierdzenie w orzeczeniu WSA w Warszawie ${ }^{41}$. Ponadto, NSA słusznie wskazuje uzasadnienie istnienia autonomii prawa podatkowego - „swoiste dla tego prawa instytucje prawne, siatkę pojęciową oraz metodę regulacji"42. $\mathrm{Z}$ tego poglądu wynika uzasadnienie do ustanawiania w przepisach ustaw podatkowych definicji działalności gospodarczej w szerokim ujęciu poprzez opis cech determinujących prowadzenie działalności gospodarczej, a nie poprzez wskazywanie rodzajów przedmiotu działalności gospodarczej. Dzięki temu rozwiązaniu nowo powstałe gałęzie gospodarki byłyby objęte zakresem podmiotowym poszczególnych ustaw podatkowych.

Ustawodawca powinien zmienić treść art. 15 ust. 2 ustawy o VAT, aby uniknąć podwójnego definiowania działalności gospodarczej w rozumieniu tej samej ustawy. Najlepszym wyjściem byłoby przeniesienie na grunt polskiej ustawy o VAT definicji działalności gospodarczej zawartej w art. 9 ust. 1 dyrektywy o VAT. Artykuł 9 ust. 1 dyrektywy o VAT określa role, które może przyjąć przedsiębiorca w obrocie gospodarczym i to, w jaki sposób mogą one być pełnione. Polski ustawodawca mógłby dopełnić ten przepis poprzez wzmiankowanie o zorganizowanym oraz ciągłym charakterze działalności gospodarczej, co stanowi przesłanki uznania działalności za działalność gospodarczą w rozumieniu polskiego prawa gospodarczego publicznego. Przedstawiciele nauki postulowali, aby ustawy podatkowe odwoływały się do definicji działalności gospodarczej zawartej w ustawie - Prawo przedsiębiorców ${ }^{43}$, lecz takowe posunięcie byłoby niezgodne z postanowieniami dyrektywy o VAT. Zastosowanie definicji działalności gospodarczej w rozumieniu ustawy Prawo przedsiębiorców w ustawie o podatku od towarów i usług byłoby niezgodne $\mathrm{z}$ art. 9 ust. 1 dyrektywy o VAT, ponieważ brakowałoby w takiej definicji elementu udowodnienia, że podatek od towarów i usług jest

41 Wyrok WSA w Warszawie z 28 lutego 2017 r., III SA/Wa 451/16, «Lex» nr 2387469.

42 Wyrok NSA z 24 czerwca 2015 r., I FSK 390/14, «Lex» nr 1783228.

43 J. Bielawny, W. Modzelewski, Ile ustaw, tyle definicji, «Rzeczpospolita» nr 11 z 8 listopada $2010 \mathrm{r}$. 
podatkiem, gdzie opodatkowywana jest konsumpcja, a rzeczywistym podatnikiem tego podatku jest konsument.

Jak już zostało wspomniane w poprzedniej części niniejszego artykułu, polski ustawodawca powinien podjąć na podstawie art. 395 ust. 1 dyrektywy o VAT działania legislacyjne dążące do wyłączenia od podatku od towarów i usług osób wykonujących działalność nieewidencjonowaną. $Z$ powodu zwolnienia od podatku od towarów i usług sprzedaży poniżej 200000 zł, skutki finansowe takiego rozwiązania nie powodowałyby zbyt dużego uszczerbku dla ogólnej kwoty wpływów państwa członkowskiego z tytułu podatku VAT, a odciążałyby osoby trudniące się działalnością nieewidencjonowaną od obowiązków związanych z udowodnieniem nieprzekroczenia progu 200000 zł niezależnie od wartości dokonywanej sprzedaży.

Na gruncie ustawy o PIT ustawodawca powinien dostosować definicję zawartą w art. 5a pkt 6 ustawy o PIT do nowej definicji działalności gospodarczej, zawartej w ustawie - Prawo przedsiębiorców. Interpretowanie obecnej definicji w ustawie o PIT byłoby trudne, jeżeli pojawiłyby się nowe rodzaje działalności, nieodpowiadające obecnej definicji. Definicja w ustawie - Prawo przedsiębiorców prowadzi do tego, że każdą zorganizowaną, ciągłą oraz zarobkową działalność uzna się za działalność gospodarczą, niezależnie od tego, na czym ona będzie polegała.

DZIAŁALNOŚĆ GOSPODARCZA W ROZUMIENIU USTAWY O PODATKU OD TOWARÓW I USŁUG ORAZ USTAWY O PODATKU DOCHODOWYM OD OSÓB FIZYCZNYCH

\section{Streszczenie}

Celem autora było przedstawienie zrealizowania zasady autonomii prawa podatkowego w stosunku do definicji działalności gospodarczej, która stanowi prawne odzwierciedlenie zjawiska ekonomicznego. Autor przedstawił definicję działalności gospodarczej określoną w przepisach ustaw podatkowych i porównał pod względem prawnym wyżej wymienione definicje z definicją określoną na podstawie ustawy z 6 marca 2018 r. - Prawo przedsiębiorców (Dz. U. z 2019 r. poz. 1292 ze zm.). Autor 
analizował powiązania pomiędzy definicjami działalności gospodarczej a realiami obrotu gospodarczego i przedstawił błędy legislacyjne zawarte w definicjach działalności gospodarczej zawarte w ustawach podatkowych. Dokonano analizy w zakresie możliwości zniwelowania obowiązków podatkowych u osób prowadzących działalność nieewidencjonowaną w rozumieniu ustawy - Prawo przedsiębiorców. W niniejszym opracowaniu w odniesieniu do badania aktów prawnych zostały wykorzystane dwie metody: dogmatycznoprawna oraz historycznoprawna. Badania zostały przeprowadzone przy użyciu krytycznej analizy orzecznictwa sądów administracyjnych oraz Trybunału Sprawiedliwości Unii Europejskiej.

Business Activity as Defined in the Polish VAT Act and Personal Income Tax Act

\section{Summary}

My aim in this paper is to present the implementation of the principle of autonomy of tax law in relation to the definition of business activity, which is a legal reflection of the economic process. I present the definition of business activity in the provisions of Polish fiscal legislation and compare these definitions in legal terms with the definition given in Ustawa $z 6$ marca 2018 r. - Prawo przedsiębiorców (the Act of 6 March 2018: the Law on Entrepreneurs; Dziennik Ustaw 2019, Item 1292, as amended). I analyse the relationship between the definitions of business activity and the reality of business transactions, and identify legislative errors in the definitions of business activity contained in Polish fiscal legislation. I examine the potential for the tax exemption of persons conducting unregistered business activities within the meaning of the Law on Entrepreneurs. I use two methods to review the legislation, the dogmatic legal method and the historical legal method. I conducted my research using a critical analysis of the case law of Polish administrative courts and the EU Court of Justice. 
Słowa kluczowe: działalność gospodarcza; dyrektywa o VAT; ustawa o podatku od towarów i usług; ustawa o podatku dochodowym od osób fizycznych.

Keywords: business activity; the VAT directive; the Polish Value-Added Tax Act; the Polish Personal Income Tax Act.

\section{Literatura}

Bielawny J., Modzelewski W., Ile ustaw, tyle definicji, «Rzeczpospolita» nr 11 Z 8 listopada $2010 \mathrm{r}$.

Borszowski P., Działalność gospodarcza w konstrukcji prawnej podatku, Warszawa 2010, «Lex/el.».

Brzeziński B., Podstawy wykładni prawa podatkowego, Gdańsk 2018, s. 74.

Budziszewski J., Żarkowska A., Opodatkowanie dostawy udziału w prawie wieczystego użytkowania niezabudowanej działki gruntu, «Doradztwo Podatkowe» 12/2014, s. 9-11.

Gajewski P., Polityka ustawodawcy w zakresie podejmowania, wykonywania izakończenia działalności gospodarczej, «Studenckie Zeszyty Naukowe» 21.38/2018, s. 45-46.

Gibasiewicz D., Zasada neutralności podatku od wartości dodanej w orzecznictwie Trybunału Sprawiedliwości Unii Europejskiej, Warszawa 2012, «Lex/el.».

JAMroży M., Działalność gospodarcza czy inne źródło przychodów - łamigłówka nie do rozwiązania?, «Przegląd Podatkowy»10/2014, s. 7-9.

KŁoskowski K., Sprzedaż nieruchomości przez osoby fizyczne nieprowadzące działalności gospodarczej a status podatnika na gruncie VAT, «Doradztwo Podatkowe» 2/2007, s. 11.

Koszowski M., Autonomia prawa podatkowego - argumenty za i przeciw, «Przegląd Prawa Publicznego» 11/2013, s. 42-56.

Mariański A. (red.), Opodatkowanie działalności gospodarczej w Polsce, Warszawa 2016, «Lex/el.».

Nizio€ K., Prawne aspekty polityki podatkowej, Warszawa 2007.

Rutkowska-Brdulak A., Stałe miejsce prowadzenie działalności $w$ VAT a podmiotowość prawnopodatkowa. Dylematy, konsekwencje, ryzyka, Warszawa 2018 , s. 43 , s. 45.

Szuladziński T., Definicja podatnika a opodatkowanie sprzedaży nieruchomości podatkiem od czynności cywilnoprawnych i VAT, «Nowy Przegląd Notarialny» 4/2005, s. 87. 
Szuladziński T., Podatnik VAT w nieprofesjonalnym obrocie gospodarczym istotna zmiana interpretacji, "Nowy Przegląd Notarialny» 3/2011, s. 85-89.

WesoŁowska A., Pojęcie „podatnika” oraz „osoby prowadzącej działalność gospodarcza" dla potrzeb podatku VAT. Glosa do wyroku TS z 13 czerwca 2013 r., C-62/12, «Lex/el.». 